buted to rubella, and according to whether the cases of Ewing's tumour and Still's disease are believed to have been due to mumps there are only two, three, or four deaths unrelated to the infections. A possible explanation for some of the deficit is that the pregnancies studied included fewer than "expected" from social classes IV and V (as defined by the Registrar General) where child mortality is highest. Such a bias, however, would not influence the argument on leukaemia because childhood leukaemia does not vary with social class. Despite the difficulty in interpreting the causes of these few deaths we incline to accept the finding which is positive and in keeping with the hypothesis that chickenpox in pregnancy is related to leukaemia in the child. So far as we know this association has not been reported before, although Stewart et al. (1958) noted two cases of leukaemia after herpes zoster in pregnancy. (They also noted one leukaemia case after mumps.) The conclusion is strengthened by the finding (Fedrick and Alberman, 1972) that cases of influenza in pregnancy were followed by a greatly increased number of diagnoses of leukaemia in the children, and also by previous reports of the effects of other virus infections. Stewart et al. (1958) noted leukarmia after maternal infectious hepatitis and lymphoblastoma after rubella.

Our findings and those mentioned above (supported by what is known from animal experiments) show that a proportion of childhood leukaemia cases are associated with virus infections; the disease may even be a nonspecific reaction to virus infection in pregnancy. It remains to be shown whether different infections carry different risks, and whether certain groups affected by the same virus are at special risk. In this respect we do not know whether there is any significance in the recorded statement that the mother in case 1 was suffering from chickenpox for the second time. Furthermore, since the cases reported by Fedrick and Alberman (1972) may have occurred as early as 12 weeks of:gestation and as late as 36 weeks, no critical period in gestation is yet evident, and it would be reasonable to question whether virus infections in early infancy have similar properties.

While we do not know whether either of the deaths in the mumps index cases was more than coincidentally related to the preceding infection it is reasonable to suspect that virus infections in pregnancy may have other undiscovered effects which may well include Still's disease or Ewing's tumour. That infant mortality from respiratory disease increases after influenza epidemics (Griffith et al., 1972)-an observation that has yet to be elucidated-shows that such effects can have remained undiscovered until the present.

Further investigation of the type described in this study will define which virus infections from what stages of pregnancy can lead to leukaemia and shed light on its pathogenesis with real hope for prevention or cure. It will also show what other complications can follow these infections. We have, therefore, started collecting records of further cases of chickenpox, mumps, rubella, influenza, and other virus infections in pregnancy and in infancy, to show which virus infections lead to leukaemia, and in these cases to estimate the risk and define the danger period.

We thank the Director and Registrar General of the Office of Population Censuses and Surveys for permission to report the study, our colleagues and, in particular, Miss R. M. Loy and Mr. D. J. Smale for their help, and the doctors who have given us access to their case records.

\section{References}

Fedrick, J., and Alberman, E. D. (1972). British Medical fournal, 2, 485. Griffith, G. W., Adelstein, A. M., Lambert, P. M. and Weatherall, J. A. C (1972). British Medical fournal, 3, 553

Manson, M. M., Logan, W. P. D., and Loy, R. M. (1960). Rubella and other Virus Infections During Pregnancy. London, H.M.S.O.

Stewart, A., Webb, J., and Hewitt, D. (1958). British Medical fournal, 1, 1495.

\title{
Incidence of Neoplasms in Children Born after Influenza Epidemics
}

\author{
IAN LECK， J. K. STEWARD
}

\section{Introduction}

It has been suggested that children whose mothers have had influenza in pregnancy may be more likely than average to develop neoplasms of lymphatic or haematopoietic tissue (Fedrick and Alberman, 1972). The suggestion was prompted by two observations. Firstly, in a longitudinal study the incidence of these neoplasms in children whose mothers had given a history of influenza when questioned soon after delivery was found to be higher than in other children. Secondly, the statistics published routinely by the Registrar General for England and Wales suggested that the mortality from these neoplasms at ages under 5 years had been higher than average in children born in years that began during winters when influenza epidemics occurred.

The value of the statistics on year of birth was, however, rather limited, firstly, by being based only on death certificates and not allowing for survivors or for errors in certification, and, secondly, by the fact that the Registrar General does not analyse deaths by year of birth, but only by year of death and age. The numbers born in different years were estimated by halving the number of deaths recorded for each age group and calendar year and allocating half to the first and half to the second of the two years in which the relevant children could have been born.

To remedy these deficiencies we have explored the possible relation of influenza epidemics to the births of children recorded IAN LECK, PH.D., M.F.C.M., Reader, Department of Social and Preventive

J. K. STEWARD, M.D., F.R.C.P., Senior Lecturer, Departments of Child Health and of Pathology 
in the Manchester Children's Tumour Registry. Survivors as well as dead children are included, and birth dates are known.

\section{SOURCES OF DATA}

The Manchester Children's Tumour Registry was established by the Departments of Child Health and of Pathology of Manchester University to collect details of all residents of the Manchester Hospital Region with malignant or benign neoplasms who were first seen at hospital in or after 1954 at ages under 15 years (Marsden and Steward, 1968). The treatment of children's tumours in this region has been largely centralized in a few units which have close links with the registry, and the clinical notes of all registered cases and histological preparations from many of them are reviewed for the registry by specialists in paediatric oncology. The registry is, therefore, likely to include a higher proportion of cases, and to have more accurate diagnostic data, than could any series assembled from death registrations alone or from the records of less specialized cancer registries.

As in some previous studies where the prevalence of influenza could not be measured directly-for example, Leck (1971)-we attempted to define epidemics by inspecting the total numbers of new claims to sickness benefit received each week by the Department of Health and Social Security. These have been published in the weekly returns of the Registrar General since late 1949. The weekly numbers of new claims actually received in the North-West Standard Region for the year that stanted then, and for the next 19 years, were compared for each year in turn with the numbers that would have been received if the claims for the year in question had been distributed between weeks in the same propontions as the totals for the other 19 years. After inspecting the results it was decided to regard influenza as having been epidemic in every period of two or more consecutive weeks when the weekly numbers of new claims for the North-West Region exceeded the expected numbers by more than half the average weekly total for the relevant year-that is, by an amount ranging from 9,400 in 1951-2 to 15,900 in 1968-9. The expected and average weekly numbers used in applying this definition were corrected ones, based on weekly and annual totals in which the figures for weeks with epidemics were replaced by estimates of the figures to have been expected then if epidemics had not occurred.

\section{METHODS OF ANALYSIS}

To determine whether the incidence of neoplasms known to the Children's Tumour Registry varied significantly between different cohorts of children-for example, those born after epidemics and at other times-the experience of each relevant cohort was summarized by calculating its standardized incidence ratio. This index is the ratio of the observed number of neoplasms arising in a cohort to the "expected" number, which was defined for the purpose of the study as the number that would have occurred at ages under 15 in the cohort in 1954-68 if the age-specific incidence rates observed in all children in 1954-68 had applied. The reason for calculating incidence ratios rather than the incidence rates experienced by different cohorts in 1954-68 is that the rates are not directly comparable, since each cohort was passing through a different age range at the time.

To obtain the "expected" number for each cohort, the number of person-years lived by the cohort in 1954-68 during each of the first 15 years of life was multiplied by the corresponding agespecific incidence rate per person-year for the whole of 1954-68, and the 15 products were added together. The numbers of person-years used in these calculations were estimated from the mid-year population statistics published annually in the Statistical Reviews of the Registrar General. Estimation from this source is possible because the number of children at any given age in any mid-year population is virtually the same as the number of person-years lived at the same age by all the children who reached that age during the preceding 12 months. For example, if (as estimated by the Registrar General) there were 75,700 children aged under one year in the Manchester Hospital Region at the end of June 1968, it may be assumed that the number of person-years lived there during the first year of life by children born in July 1967-June 1968 was also about 75,700. This assumption can be made because at the end of this period the 75,700 children would have been fairly evenly distributed with respect to age over the range from 0 to 365 days. The figure 75,700 is, therefore, likely to be close to the mean of the numbers of children born in his period who were resident in the region on each day of life from the first to the 366th day (or the 365th if 1968 had not been a leap year). This mean is equivalent to the number of person-years lived in the first year of life by these children.

In this particular cohort, however, there were some children (those born in January-June 1968) whose first year of life extended into 1969. Person-years lived outside the period 1954-68 had of course to be excluded from our calculations, since we were analysing only neoplasms that presented within this period. The numbers of person-years to exclude were decided by reference to the monthly numbers of births in the whole of England and Wales which appear in the Annual Reviews of the Registrar General, since we had no regional data on this subject. Between July 1967 and June $196851 \cdot 13 \%$ of all births occurred in January-June, and it can be estimated from the monthly figures that $24 \cdot 79 \%$ of the person-years lived in infancy by children born in these months fell outside the calendar year of birth. It is, therefore, likely that life after the end of 1968 accounted for about $9,595(24.79 \%$ of $51 \cdot 13 \%)$ of the 75,700 person-years which we have assumed that the children born in July 1967-June 1968 lived in infancy. So far as the present inquiry is concerned, the members of this cohort can be assumed to have been at risk in infancy only for the remaining 66,105 person-years.

Similar methods can be used to find the approximate number of person-years for which any cohort is at risk at any age, provided that figures for the relevant age-specific mid-year populations are available or can be estimated. For most of the years studied such figures were not published for the Manchester Hospital Region and had to be derived from national figures at each year of age, and figures for five-year or 10-year age groups in the North-West Standard Region and its two conurbations. Firstly, we adjusted the regional figures published for 1962 and earlier years for the fact that, according to the 1961 census, they were too low. Next, the numbers in the hospital region were estimated from the other regional statistics. One conurbation, South-East Lancashire, is in the hospital region, and at the 1961 census the rest of the hospital region had $70.2 \%$ of the children in the North-West excluding conurbations. Mid-year estimates for each age group in the hospital region were, therefore, obtained by adding the numbers for South-East Lancashire to $70.2 \%$ of the figures for the NorthWest excluding conurbations. Finally, hospital region figures for each individual year of age were calculated from the five-year and 10-year estimates on the assumption that the regional population in each of these age groups was distributed between individual years of age in the same proportions as the corresponding national population.

\section{Results}

The registry covers 575 children with neoplasms of the lymphatic and haematopoietic tissues and 966 children with other neoplasms who first attended hospital in 1954-68. Age at first hospital attendance is known for all but one of these children and is shown in table I, together with estimates of incidence at each age per million person-years lived. 
TABLB I-Residents of Manchester Hospital Region aged 0-14 years who First Attended Hospital with Neoplasms in 1954-68

\begin{tabular}{|c|c|c|c|c|c|}
\hline \multirow{2}{*}{$\begin{array}{c}\text { Age } \\
\text { at First } \\
\text { Hospital } \\
\text { Attendance } \\
\text { (Completed } \\
\text { Years) }\end{array}$} & \multicolumn{2}{|c|}{ No. of Children } & \multirow{2}{*}{$\begin{array}{c}\text { Person- } \\
\text { years } \\
\text { At Risk } \\
\text { (millions) }\end{array}$} & \multicolumn{2}{|c|}{$\begin{array}{c}\text { Incidence per Million } \\
\text { Person-years }\end{array}$} \\
\hline & $\begin{array}{c}\text { Neoplasms of } \\
\text { Lymphatic and } \\
\text { Haematopoietic } \\
\text { Tissue }\end{array}$ & $\begin{array}{c}\text { Other } \\
\text { Neoplasms }\end{array}$ & & $\begin{array}{c}\text { Neoplasms of } \\
\text { Lymphatic and } \\
\text { Haematopoietic } \\
\text { Tissue }\end{array}$ & $\begin{array}{l}\text { Other } \\
\text { Neoplasms }\end{array}$ \\
\hline $\begin{array}{r}0 \\
1 \\
2 \\
3 \\
4 \\
5 \\
6 \\
7 \\
8 \\
9 \\
10 \\
11 \\
12 \\
13 \\
14\end{array}$ & $\begin{array}{l}26 \\
46 \\
81 \\
75 \\
46 \\
46 \\
43 \\
41 \\
28 \\
16 \\
25 \\
21 \\
31 \\
21 \\
28\end{array}$ & $\begin{array}{r}129 \\
122 \\
89 \\
87 \\
63 \\
60 \\
48 \\
48 \\
48 \\
53 \\
39 \\
40 \\
50 \\
47 \\
43\end{array}$ & $\begin{array}{l}1.087 \\
1.077 \\
1.059 \\
1.041 \\
1.023 \\
1.010 \\
1.004 \\
1.005 \\
0.996 \\
0.988 \\
0.982 \\
0.974 \\
0.965 \\
0.955 \\
0.948\end{array}$ & $\begin{array}{l}24 \\
43 \\
76 \\
72 \\
45 \\
46 \\
43 \\
41 \\
28 \\
16 \\
25 \\
22 \\
32 \\
22 \\
30\end{array}$ & $\begin{array}{r}119 \\
113 \\
84 \\
84 \\
62 \\
59 \\
48 \\
48 \\
48 \\
54 \\
40 \\
41 \\
52 \\
49 \\
45\end{array}$ \\
\hline All ages & 574 & 966 & $15 \cdot 114$ & $38 \cdot 0$ & 63.9 \\
\hline
\end{tabular}

By applying these age-specific incidence rates to estimates of the numbers of person-years lived in 1954- 68 by children born in different quinquennia, the numbers of neoplasms to be expected in each of these cohorts were determined. The expected and observed numbers were converted to standardized incidence ratios, which are shown together with the observed numbers in table II. They provide no evidence of any long-term trends in incidence or other significant departures from expectation. If long-term trends had occurred it might have been necessary to adjust for them before comparing incidence after influenza epidemics and at other times.

Six influenza epidemics were defined by the analysis of new claims to sickness benefit in North-West England described under Sources of Data. The estimated durations of these epidemics are given in table III, together with the strains of virus that were reported to be prevalent at these times, the numbers of new claims received, and the months when there must have been numerous children born whose mothers could have been exposed to influenza in pregnancy. Such births were assumed to have been numerous in each month that included more than seven days which coincided with an influenza epidemic or followed within 42 weeks of one. These months are listed in table III according to the stages of pregnancy when epidemics occurred. Months which included more than seven days that were between 24 and 42 weeks after epidemic periods are listed under the heading Epidemics at 0-13 Weeks, since a child whose birth was preceded by an epidemic occurring less than 14 weeks after onset of the last menstrual period could be born as little as 24 weeks later if birth was two weeks early, or as much as $\mathbf{4 2}$ weeks later if it was two weeks overdue. Analogous criteria were used to define months that would include substantial numbers of births after epidemics at 14-27 and 28 or more completed weeks of gestation.

As the sickness benefit statistics used in defining influenza epidemics were not available before late 1949 , only the children born in 1951-68 could be analysed in relation to these epidemics. Age-specific incidence rates for neoplasms in these children were therefore calculated (as in table I), as were estimates of the numbers of person-years lived in 1954-68 by children born during each of the postepidemic periods distinguished in table III. From these two sets of figures the numbers of neoplasms to be expected in each of these cohorts, if influenza did not affect incidence, were estimated and related to the observed numbers, with the results summarized in table IV. The standardized incidence ratios obtained were not significantly greater than unity for any of the cohorts born after particular epidemics nor for all these cohorts combined or for the children born after epidemics in defined trimesters of pregnancy.

TABLE IV-Standardized Incidence Ratios for Neoplasms Seen in 1954-68 in Children Born in 1951-68 (Observed Numbers are Given in Parentheses)

\begin{tabular}{|c|c|c|c|}
\hline \multicolumn{2}{|l|}{ Birth Details } & $\begin{array}{l}\text { Neoplasms of } \\
\text { Lymphatic and } \\
\text { Haematopoietic } \\
\text { Tissue }\end{array}$ & $\begin{array}{c}\text { Other } \\
\text { Neoplasms }\end{array}$ \\
\hline $\begin{array}{l}\text { Births during or following epide } \\
\text { month of birth: } \\
\text { January-November } 1951 \ldots \\
\text { September 1957-August } 1958 \\
\text { February-December } 1959 \\
\text { January-November } 1961 \ldots \\
\text { January-October } 1962 \\
\text { February-December } 1966\end{array}$ & 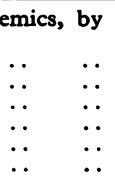 & $\begin{array}{l}0.78(20) \\
0.97(30) \\
1.17(32) \\
1.02(26) \\
0.91(20) \\
0.96(7)\end{array}$ & $\begin{array}{l}1.03(37) \\
0.93(47) \\
1.12(49) \\
0.92(38) \\
0.85(31) \\
1.33(26)\end{array}$ \\
\hline $\begin{array}{l}\text { All births during or after epidemi } \\
\text { All other births } \ldots\end{array}$ & $\begin{array}{ll}\text { ics } & \ldots \\
\ldots & \ldots\end{array}$ & $\begin{array}{l}0.97(135) \\
1.01(300)\end{array}$ & $\begin{array}{l}1.00(228) \\
1.00(495)\end{array}$ \\
\hline $\begin{array}{l}\text { Births during or after epidemics, b } \\
\text { gestation at which epidemics } \\
\text { occurred* } \\
0-13 \text { completed weeks } \ldots \\
14-27 \text { completed weeks } \ldots \\
28 \text { or more completed weeks }\end{array}$ & $\begin{array}{l}\begin{array}{r}\text { by stage of } \\
\text { may have }\end{array} \\
\begin{array}{ll} \\
\ldots & \ldots \\
\ldots & \cdots\end{array}\end{array}$ & $\begin{array}{l}0.96(66) \\
0.92(69) \\
0.99(61)\end{array}$ & $\begin{array}{l}0.90(102) \\
1.03(127) \\
1.09(109)\end{array}$ \\
\hline
\end{tabular}

* See table III for allocation of births to each group. Groups are not mutually exclusive. TABLE II-Standardized Incidence Ratios of

\begin{tabular}{|c|c|c|c|c|c|c|c|c|c|}
\hline \multicolumn{6}{|c|}{ Age at first hospital attendance (completed years) } & \multirow{2}{*}{$\begin{array}{c}0-4 \\
\bar{Z} \\
1 \cdot 16 \overline{(52)} \\
0.87(73) \\
0.97(96) \\
1.14(53)\end{array}$} & \multirow{2}{*}{$\begin{array}{c}5-9 \\
0.82 \overline{(21)} \\
1.01(55) \\
1.13(64) \\
0.92(34) \\
-\end{array}$} & \multirow{2}{*}{$\begin{array}{c}10-14 \\
1.02(19) \\
1.01(46) \\
0.88(37) \\
1.19(24) \\
=\end{array}$} & \multirow{2}{*}{\begin{tabular}{l}
\multicolumn{1}{c}{ Total } \\
$1.02(19)$ \\
$0.94(67)$ \\
$1.02(144)$ \\
$1.00(161)$ \\
$0.96(130)$ \\
$1.14(53)$
\end{tabular}} \\
\hline \multirow{2}{*}{\multicolumn{5}{|c|}{ Neoplasms of lymphatic and haematopoietic tissue }} & $\begin{array}{l}1939-43 \text { births } \\
1944-8 \text { births } \\
1949-53 \text { births } \\
1954-8 \text { births } \\
1959-63 \text { births } \\
1964-8 \text { births }\end{array}$ & & & & \\
\hline & & & & & Probability ( $\chi^{2}$ test) & $0.5>P>0.3$ & $0.7>P>0.5$ & $0.8>P>0.7$ & $0.95>P>0.90$ \\
\hline \multirow[t]{2}{*}{ Other neoplasms } & \multirow{2}{*}{\multicolumn{2}{|c|}{$\cdots \quad \cdots$}} & \multirow[t]{2}{*}{$\cdots$} & \multirow[t]{2}{*}{. } & $\begin{array}{l}1939-43 \text { births } \\
1944-8 \text { births } \\
1949-53 \text { births } \\
1954-8 \text { births } \\
1959-63 \text { births } \\
1964-8 \text { births }\end{array}$ & $\begin{array}{c}\overline{-} \\
1.02 \overline{(64)} \\
0.99(148) \\
0.96(168) \\
1.06(110)\end{array}$ & $\begin{array}{l}1.05 \overline{(47)} \\
0.96(78) \\
1.02(86) \\
0.97(46) \\
-\end{array}$ & $\begin{array}{c}1.16(38) \\
1.14(90) \\
0.82(60) \\
0.90(31) \\
=\end{array}$ & $\begin{array}{l}1.16(38) \\
1.11(137) \\
0.93(202) \\
0.99(265) \\
0.96(124) \\
1.06(110)\end{array}$ \\
\hline & & & & & Probability ( $x^{2}$ test) & $0.9>P>0.8$ & $0.98>P>0.95$ & $0.2>P>0.1$ & $0.7>P>0.5$ \\
\hline
\end{tabular}

TABLE III-Influenza Epidemics Defined by Analysing New Claims to Sickness Benefit

\begin{tabular}{|c|c|c|c|c|c|c|}
\hline \multirow{2}{*}{ Epidemic Period* } & \multirow{2}{*}{$\begin{array}{l}\text { Strain } \\
\text { of Virus } \\
\text { Isolated }\end{array}$} & \multicolumn{2}{|c|}{$\begin{array}{c}\text { New Claims to Sickness } \\
\text { Benefit in North-west Region }\end{array}$} & \multicolumn{3}{|c|}{ Principal Months of Birth for Pregnancies Coinciding with Epidemics* } \\
\hline & & Observed & Expected* & Epidemic at 0-13 Weeks & Epidemic at 14-27 Weeks & Epidemic at 28 or More Weeks \\
\hline $\begin{array}{l}27 \text { December 1950-6 February } 1951 \\
\text { 4 September-22 October } 1957 \\
\text { 11 February-10 March } 1959 \\
\text { 11 January-14 February } 1961 \\
27 \text { December 1961-16 January } 1962 \\
\text { 2 February-1 March } 1966\end{array}$ & $\begin{array}{l}\text { A prime } \\
\text { A2 } \\
\text { A2 } \\
\text { A2 } \\
\text { B } \\
\text { A2, B }\end{array}$ & $\begin{array}{l}383,900 \\
486,900 \\
220,700 \\
306,800 \\
225,800 \\
235,200\end{array}$ & $\begin{array}{l}167,100 \\
146,700 \\
121,000 \\
161,200 \\
112,200 \\
161,100\end{array}$ & $\begin{array}{c}\text { June-November } 1951 \\
\text { February-August } 1958 \\
\text { August-December } 1959 \\
\text { July-November } 1961 \\
\text { June-October } 1962 \\
\text { July-December } 1966\end{array}$ & $\begin{array}{c}\text { March-August } 1951 \\
\text { November 1957-April } 1958 \\
\text { April-September } 1959 \\
\text { March-August } 1961 \\
\text { March-July } 1962 \\
\text { April-September } 1966\end{array}$ & $\begin{array}{c}\text { January-May } 1951 \\
\text { September 1957-January } 1958 \\
\text { February-June } 1959 \\
\text { January-May } 1961 \\
\text { January-April } 1962 \\
\text { February-May } 1966\end{array}$ \\
\hline
\end{tabular}

*See text for definition. 


\section{Discussion}

In their longitudinal study of children born in Great Britain during one week of March 1958, Fedrick and Alberman (1972) found that $11.7 \%$ of mothers had reported influenza in pregnancy when questioned soon after delivery, and that during the next 11 years the children of these mothers had nine times the incidence of neoplasms of lymphatic and haematopoietic tissue found in other children. They concluded that, in general, children born after maternal influenza probably have at least four times the average liability to these neoplasms.

An excess of this order among the children of mothers who had had influenza would be likely to have a substantial effect on incidence among all children born after epidemics. For example, if the influenza attack rate among pregnant women reported by Fedrick and Alberman (11.7\%) had been typical of the 1957-8 epidemic, a quadrupling of the incidence of lymphatic and haematopoietic neoplasms in the children of the affected women coupled with an average incidence in the other $88.3 \%$ would have produced an overall incidence of $((4 \times 11 \cdot 7)+88 \cdot 3)$ or $135 \cdot 1 \%$ of the average. Moreover, it seems likely that the true attack rate (and, therefore, the incidence of neoplasms predicted by the hypothesis of Fedrick and Alberman) was higher than the information supplied by the mothers after delivery would suggest. Such information is often incomplete, and studies of general practice records made at the time of the 1957-8 epidemic suggest that at least one-fifth of young adults may have been affected (Fry, 1958; Woodall, Rowson and McDonald, 1958; Ministry of Health, 1960).

In the North-west of England, where the present series originated, sickness benefit statistics suggest that the attack rate in the 1957 epidemic was at least as high as the national average, and that the mean of the attack rates for the six influenza epidemics that were noted during the prenatal lives of children born in 1951-68 (table III) was about $46 \%$ of the 1957 rate. It follows that even if the national attack rate among pregnant women in 1957-8 had been as low as the figure given by Fedrick and Alberman, the rate in the North-west would probably have been at least $11.7 \%$ then, and have averaged not less than $5.3 \%$ $(46 \%$ of $11.7 \%$ ) for all six epidemics. In these circumstances, a quadrupling of the incidence of lymphoid and haematopoietic neoplasms in the children of women attacked by influenza in pregnancy would, as already indicated, have increased their incidence by $35 \cdot 1 \%$ among all children born after the 1957 epidemic; and the overall increase among all those born after any of the six epidemics would have been $15.9 \%$.

In the present series, however, both the children born after all six epidemics and the subgroup born after the 1957 epidemic alone included no more cases of these neoplasms than would have been expected if influenza did not affect incidence (table IV). These findings are difficult to reconcile with the hypothesis that influenza quadruples the risk-the more so because the numbers of cases observed, both in the group born after all epidemics and in the 1957-8 subgroup, fell below the lower $95 \%$ confidence limits (with one tail) of the increases predicted by this hypothesis.

Apart from random variation, two possible explanations may be suggested for the apparent contradiction between this negative finding and the high nationwide incidence of neoplasms reported in children whose mothers had influenza. If the association between maternal influenza and childhood neoplasia is one of cause and effect, the incidence of neoplasms must be increased in children born after epidemics and our failure to detect it must be due to some bias in the Manchester data. Alternatively, the association may not be causal.

The main evidence to support the first suggestion is the fact that mortality from lymphoid and haematopoietic neoplasms in all children born after influenza epidemics was estimated to be relatively high by Fedrick and Alberman when using national data. But these figures, unlike those for the Manchester region, related only to 10 years' births, and were not actual incidence rates for these cohorts but only estimated mortality rates derived from the numbers dying each year at different years of age. A further point in favour of the Manchester series is that its distribution by quinquennium of birth (table II) does not suggest any bias. There is for example no evidence of any secular trend that might have affected the comparability of postepidemic and other periods.

There remains the possibility that the association between maternal influenza and childhood neoplasia, although real, may not be causal. In other words, the characteristics which make some women more prone to influenza than others may include factors which predispose to neoplasms in their children regardless of whether these women become infected. It seems possible that some immunological deficiencies may have these properties, since many deficiencies of this kind seem to predispose to reticuloendothelial neoplasia (Doll and Kinlen, 1970), and some are genetically transmitted. Factors like these could lead to the incidence of neoplasms being higher in children whose mothers have had influenza than in other children, but not higher after epidemics than at other times.

The data of the Manchester Children's Tumour Registry were analysed on the National Computer Centre's ICL 1905F computer. We are grateful to Mr. David Medford and Mr. Michael Palmer for carrying out this analysis, and to Mrs. Nina Rowe and Mrs. Evelyn Townsend for secretarial help.

\section{References}

Doll, R., and Kinlen, L. (1970). British Medical fournal, 4, 420

Fedrick, J., and Alberman, E. D. (1972). British Medical fournal, 2, 485. Fry, J. (1958). British Medical fournal, 1, 259.

Leck, I. (1971). H.S.M.H.A. Health Reports, 86, 265

Marsden, H. B., and Steward, J. K. (1968). Tumours in Children. Berlin, Springer.

Ministry of Health (1960). Influenza Epidemic in England and Wales, $1957-$ 1958. London, H.M.S.O.

Woodall, J., Rowson, K. E. K., and McDonald, J. C. (1958). British Medical Fournal, 2, 1316. 